\title{
Review on Development Concept Researches
}

\author{
Farouk Abdullah Alwyni \\ Perbanas (The Association of National Banks) Institute \\ Universiti Sains Malaysia
}

The question on why some countries succeeded while others failed in their development efforts attracts many researches on the concepts of development. There has been no easy answer to that, and it seems there is no single concept that can fit for all. The success of one country with one set of policies may not be applicable to other countries. Indeed, there are aspects that can be learned from those considered successful in their development efforts, but a full-fledge adoption without taking into consideration specific contexts that one country has may not result in desirable outcome. Hence, this study aims to undertake a review on previous researches related to development concepts, their implementation in developing countries, and the outcome based on that implementation. The research methodology applied will be based strictly on past researches on the subjects. The study found that the concepts of development should not just rely on dominant Western-based development theories considering that development was a unique process for each and every country.

Keywords: development concepts, developing countries, discourses, development, progress

\section{INTRODUCTION}

Studies on development have been increasingly popular after around the end of World War II. It was around the same time with the establishment of the Breton Wood Institutions such as World Bank (WB) and International Monetary Funds (IMF). The end of World War II signifies two main things related to development. First, the reconstruction efforts of those countries in Europe and Asia destroyed by the War took place. Secondly, many developing countries in Asia, Africa, and Latin America just gained their independence from colonialism and needed to develop primarily their own economy.

Hence, this study will review previous researches related to development concepts. In researching the discussion on development concepts, this study encounters so many previous researches in the subject. Most of previous researches on the topics related to development will mostly first discuss the concepts of development itself along with its intellectual underpinnings. Of those selected previous researches, this study identifies that those past researches can be put into two main categories. First, researches that deal with countries' case in discussing about development. Secondly, researches that discuss more on the intellectual aspects of the development itself.

Those researches falling under the first theme are done by by Anjuman Ali-Bogaert (1997), Bidney (2009), Borda-Rodriguez (2008), Lysaght (2008), and Walton (2017). Whereas for the second theme are done by Aftab (2003), Ben Meir (2009), Briant (2015), Burr (2010), Grant (1998), Holmsten (2003), and Ramirez-Faria (1989). The following sections will review those mentioned researches. 


\section{DEVELOPMENT CONCEPT: COUNTRIES' CASE STUDIES}

On the first category of study, those researches study development related issues in India, Mongolia, Bolivia, Indonesia, and Sub-Sahara Africa. Anjuman Ali-Bogaert (1997) and Bidney (2009) explored the concepts of development based on their field study in India and Mongolia respectively.

Anjuman Ali-Bogaert (1997) wrote about the concept of alternative to development based on one major dam project in India (Narmada Valley Project [NVP]) and it was opposed by the local communities affected by the project, led by a community group called Narmada Bachao Andolan. The author proposed that the whole of ideas of the discourse of development should be questioned if they just relied on the dominant Western discourses of development be they in the right or left, such as the modernization theory, classical and neo-classical economic theories, dependency theory and to the Marxist theories.

Similar with Anjuman Ali-Bogaert (1997), Bidney (2009), using the case of Mongolia, showed that the concept of development should not just rely on dominant development theories. Here, he also discussed about globalization. Bidney (2009) did the study using the experience of four people with different background and explored their understanding of development. Based on this study, he argued that how the notion of development created a mixed response between those who were in favor and those who were not. It was found out that based on their own different experience each one has her/his own conception of development.

In view of the above, he saw the need to see the meaning of development from a deeper perspective, which was through the lens of an individual experiencing on his/her own. Thus, the author criticized the approaches of two dominant development theories i.e. modernization \& dependency theories as not that really relevant with the realities in the developing countries. The author argued that "there is no one way to study development, just as there is no one definition of what it is."

In the same tone with Bidney (2009), Anjuman Ali-Bogaert (1997) argued that the right of the community should be respected in a way on what was good for them. He contended that development based on the Western understanding adopted by the elites in the developing countries should not just be imposed on people. Using the case of NVP, the author showed that actually people and/or local communities know what is good for them. Their opinion should be taken into consideration when the government of developing countries wanted to do 'development projects' affecting the local communities. They could not just adopt the mentality of the 'white man burden' and underestimated the capacity of the local communities in choosing the life they preferred.

Therefore, he challenged all Western-based dominant discourses of development and argued that they were not necessarily compatible with the local cultures \& religions. Local communities might have their own vision on what constitutes a good society, a society that they wanted to live in. The author basically was deconstructing the whole notion of development, and even raised again the basic question of what was development. Using the case of NVP, the author showed that the local community basically was vibrant and knowledgeable on how to lead their lives.

He saw that they did not need to be taught on standards not on their own. Imposing outside standards on them was actually belittling them and saw them as inferior being. So, the author concluded that any studies on the people of developing countries should respect that "societies and groups have the right to live in their own ways and that these ways are valuable. In these ways are reasons for hope - that people can forge their own modernity, their own responses to day-to-day changes and challenges."

The main point that we could draw from the above two studies was that development is a unique process for each and every country, and thus; Western-based development concepts should not be imposed on nonWestern developing countries.

Other studies done by Borda-Rodriguez (2008) and Lysaght (2008) asserted that the imposition of Western-based dominant development discourses was in fact had taken places through many different forms in developing countries. Using the case of Bolivia, Borda-Rodriguez (2008) researched on the processes of the knowledge production and dissemination for development in the work of consultants and advisors. He found that how dominant development discourses framed the knowledge engagement and the perception of consultants and advisors in the field of development assistance. 
It also found that actually consultants, advisors, and beneficiaries/clients reflect, learn, and hence produces rich knowledge individually but they could not openly share with their organizational hierarchies because it could challenge the development discourse that has been framed. In discussing that the author saw that there are three inter-connected senses of development that shaped the field of development assistance. These are:

(i) A vision of what constitutes a desirable society;

(ii) A historical process of social change in which societies are transformed over long periods. This sense is largely associated with the development of capitalism over time;

(iii) Deliberate efforts aimed at improvement on the part of various agencies.

Within the above context, the author raised the issue about the prevailing conception of what constitute with the term "improvement." Here, the vision, according to the author, might be a Western society and its associated lifestyle. Thus, the efforts done in making improvement would inevitably follow the historical process of capitalist development. Thus, the author contended that the main multilateral (World Bank, International Monetary Fund) and bilateral (donor country aid agencies such as the UK Department for International Development - DFID) development agencies would assume that "capitalist development is the only game in town, and only by embracing it will there be progress in poor countries."

In similar fashion, Lysaght (2008) examined the advice given by the International Monetary Fund (IMF) during and after the Asian crisis (1997-98) and its impact on corruption and Foreign Direct Investment (FDI). In his research, the author saw that IMF's advice was strongly influenced by the key tenet of neoliberalism on the primacy of the so-called free market. The author saw that how during that period neoliberal doctrine had become the main intellectual underpinning of the IMF as well as the World Bank in prescribing development policies for developing countries.

In this thesis, Lysaght (2008) unraveled the failure of IMF in implementing its neoliberal project in Indonesia. IMF according to the author failed to achieve the very objectives that it wanted to achieve, that it wanted to dismantle the power of oligarchy, eradicate corruption, and attract the foreign direct investment back to Indonesia. It all did not happen between the period of 1998-2005. The author saw that neoliberal theories on deregulation, privatization, and market dominance clung unnecessarily and imposed on developing countries by the IMF were inadequate and damaging to developing countries.

On the story of Sub-Sahara Africa, Walton (2017) explored the concepts of wellbeing and sustainable development in rural Sub-Sahara Africa. This was in response to what Walton found a persistent failure of free market capitalism development paradigm in the history of development discourses \& approaches in Sub-Saharan Africa. This research was basically in line with the researches of Borda-Rodriguez (2008) and Lysaght (2008) on how the application of capitalist development discourses resulted in failure in developing countries.

$\mathrm{He}$ argued that "the growth-oriented capitalist economic model that has shaped the operative understanding of wellbeing and perpetuated the invented reality of underdevelopment also guides largescale sustainable development efforts that persistently fail to significantly improve wellbeing among rural communities." He contended that understanding discourses and approaches were important because they influenced development policies, practices, goals, and outcomes, and they also directly impact community wellbeing.

In his research, Walton saw that one major challenge facing the improvement of wellbeing among marginalized rural communities in Sub-Sahara Africa was the application of an inappropriate paradigm on development. Walton argued that ecological economics may provide a paradigm for sustainable development that is culturally, ecologically, and economically more appropriate - and more effective - for both assessing and improving wellbeing.

In the above, we have seen researches discussing about conventional development concepts and their implication on the countries studied. Now, some studies purely discussed intellectual origins of the development and/or the concept of development from conventional perspective will be reviewed. 


\section{INTELLECTUAL ASPECTS OF DEVELOPMENT CONCEPTS}

In researching intellectual aspects of development, the studies can be put at least into three categories. First, it is related to the dominant concepts of development and why there is a need to come up with alternative approaches to development. These studies are conducted by Aftab (2003), Ben-Meier (2009), Burr (2010), Grant (1998), and Holmsten (2003). Secondly, those researches that showed how discourses, concepts, and thoughts on development affect approaches, policies, and implementation in the field. These researches are done by Briant (2015), Burr (2010), and Holmsten (2003).

Here, the studies of Burr (2010) and Holmsten (2003) are basically intersected with the first category of study. Finally, it is the study on a number of development thoughts done by Ramirez Faria (1989) who made him conclude that development is possible in developing countries, as opposed to some views that saw difficulties in the development of those considered as 'Third World' countries.

Falling within the first category of the study above, Aftab (2003) used more philosophical approach in digging into intellectual origins of development concepts. He saw that the current understanding of development leading to progress originated intellectually from the Western renaissance intellectuals such as Hobbes, Rousseau, Kant, and Hegel. He contended that in its development pursuit, "humankind has committed to a specious understanding of progress." Furthermore, he also opined that "dominant discourse has implicitly taken on the speculative understanding of progress most fully expounded by Hegel."

He argued that the concept of development was more Eurocentric. It focused more on the material achievement although he acknowledged that this might also contribute to happiness. His point of contention was that when development project attempted to reach a supposedly final end of development, which was the happiness, the concept of the happiness itself was one conceived in the West. Although he somehow agreed that all efforts of development would at the end be aimed toward happiness, but this concept of happiness itself could not be imposed just from existing (Western based) dominant paradigm of development.

His critique on dominant view of development was also shared by Burr (2010). She also saw that the worldview of progress utilized in development discourse was not universal. Rather, it was influenced by positivism and the historic-politico context of the Western enlightenment. Thus, she argued that the concept of progress through planned intervention was not inherent to the concept of development, but it was more as a discursive shift that came about in the evolution of Enlightenment discourse.

Here, the author showed the other concept called 'the cycles of survival.' The author stated that "the cycles of survival perspective understand deliberate interventions and attempts at social control to still be subject to non-human processes in the environment and unpredicted forces."

This perspective according to the author considered that progress was a natural process of evolution in which change came over a long period determined by a multiplicity of factors. In showing this perspective, the author wanted to show that there was other perspective that did not necessarily subscribe to theories of development which advocate that genuine progress results from the appropriate human-directed interventions. So, the author argued that basically the definition of progress and the interventions deemed appropriate to achieving it were value-based judgments. Here, the research also pointed out that the values of development should not be seen as independent of their historical emergence alongside the advent of capitalism and colonialism.

In fact, using critical theories of post-colonial and post development, the author criticized the perpetuation of states of domination and material and discursive inequality within the development context through a 'will to knowledge' over the other. Based on the studies on the experiences of development workers, Burr (2010) contended that "development projects can be a convenient mechanism for subjects in the global North to fulfill the norms of their subject positions and their personal desires of exploring, saving and changing the global South in their own image."

Here, she argued that development was often conceptualized in terms of the dominant norm offered by the global North. While in facts, the author opined that beyond the ideologies of development and capitalism there are alternative subaltern models of holistic wellbeing. The author also showed that there are a variety of development objectives under many different paradigms. She continued that the term 'development' 
itself signified a broad range of processes intended to achieve a 'progressive end' that includes development as economic growth, meeting basic material needs, human empowerment and capacity building, the expansion of rights and freedoms and cultural transformations.

At the end, both recommended alternative approaches to development. Instead of treating happiness as the end of development, Aftab (2003) basically proposed that autonomy should be the end of development. Autonomy here basically is the freedom that one society has to determine their own indicators of happiness considering the current understanding of happiness as the end of development are ideas that may not be universal. Whereas Burr (2010) proposed that in the face of the genuine existence of suffering in the contemporary global system, there had to be a flexible, self-reflexive practice of ethos that could speak to the aspirations of individuals in both privileged and subaltern positions to find commonalities with one another and work towards a more equitable world.

While somehow shared the views of Aftab (2003) and Burr (2010) in evaluating critically the conventional concept of development, Bein-Meir (2009) offered a different alternative. He proposed the concept of what he called 'alternative - participatory development.' He considered the need to come up with the concept of participatory development considering that the concept of development itself in its implementation, according to Alternative Development \& Post Development discourses, was considered "not working, being ideologically-driven, disturbing a state's equilibrium, and seeking to achieve a Westernization of the world."

In this study, he came up with a number of definitions that include among others the definition of development as a process that considered in its planning economic, social, political, cultural, institutional, environmental, and technological factors to achieve its goal of generating benefits in these areas directed at all or the majority of people, especially the poor and the definition of community development as a process of building the capacity of most or all the people of a community in order to manage development that addresses economic, social, political, and environmental objectives, and utilizes internal and external resources to improve human conditions.

The main finding that the author put forward was that the concept of Alternative - Participatory Development combines some development discourses previously prevailing in the intellectual circles on development. These were Modernization-Globalization, Socialism-Marxism, and Dependency. The author saw that all aspects related to these discourses such as community, self-reliance, empowerment, local projects that meet priority needs, capacity building, decentralization, and civil society were met in the concept of alternative - participatory development. Where they would strengthen one another and produce community development able to take root and transform broadly development processes of society that would make sustainable development possible.

Finally, the last two studies falling into the above mentioned first category that criticized the dominant concepts of development and offered compelling reasons on the need to come up with alternative approaches to development were done by Grant (1998) and Holmsten (2003).

While Grant (1998) saw the failure of neo-modernizing and neo-marxist theory contributed to the impasse of development theory, Holmsten (2003) focused more on the failure of dominant neo-liberal discourse in delivering prosperity to the world.

Grant (1998) investigated the development theory said to be at an impasse because of the 'failure' of neo-modernizing and neo-Marxist theory. The research assessed the potential of postmodernism to offer an alternative. However, after researching the impasse, the basics of postmodernism, and postmodernism's strengths and weaknesses, the researcher saw that postmodernism would not be suitable for the task. The research argued that the concept of postmodernism itself needed to be reoriented so that it would be able to synthesize development theory on the basis of a combination between interest and ethics driven development imperatives.

The reasoning that drove the author to come up with the alternative development theory was that the current version of the theory was not that fit to be the basis of 'desirable' society. He saw that there was an urgent need to morally reflect on a society's basic goals considering that things like economic growth and modernization might be morally problematic and in need of replacement, modification, or supplementation with more adequate concepts of "fullness of being".' 
The study envisioned that the synthesized development theory, if it succeeded, would offer a new alternative paradigm on development, the one that would go beyond the existing dominant parameters of "the victory of the 'democratic' and the 'free' over the dark forces of socialism, the universal pursuit of 'free markets, free speech, and free elections', and the end of history."

He saw that there was no reason to assume that the above parameters considered rigid would never change. The research contended that at the end, to be relevant and powerful enough to offer an alternative, the new reoriented postmodernism would need to offer a new model that is superior and preferable to existing models. In addition, it needs to have a strong ethical foundation in light of the pressing environmental, socio-economic and political problems in the South.

Different with the above, Holmsten (2003), using discourse analysis, examined the neoliberal discourse considered by its supporters to be the best path for economic growth through the free market to achieve poverty reduction. Neoliberalism is one important development discourse affecting policies in many developed and developing countries as well as in two major international financial organizations, the World Bank (WB) and International Monetary Fund (IMF) starting in 1980s.

However, using the facts that there were still hundreds of millions of people struggle against poverty and hunger, he argued that it was about time that this development discourse was to be evaluated. The author also argued that the path to development should not be confined only one discourse. Here, the author used the cases of Malaysia and Indonesia during the Asian financial crisis. In which, it was shown that Malaysia did not subscribe to the neoliberal discourse in dealing with the crisis, yet, it somehow managed the crisis well. In view of this, the author showed at least three implications of the study.

First, the study put forward that discourse created policies. On one hand, neo liberal discourse made IMF and World Bank prescribed policies such as trade liberalization, market integration, and global market stability as path for development for those countries obtaining financial aid from them. On the other hand, the case of Malaysia showed that there was an alternative discourse, and thus; other policies were possible.

Secondly, the research saw that while discourse might limit the debate about the best route to poverty reduction, alternative models have surfaced. The Malaysian case revealed that once there was an alternative plan, followers of the neoliberal model criticized those articulating alternative plans.

Finally, the research argued that given persistent hunger and inequality in the world, there was an opportunity to reconsider the neoliberal economic model. The author pointed out that as the work of Karl Polanyi, Caroline Thomas, and Paul Krugman suggested, there might be recognized cracks in the discourse already. As the research seemed to convey that considering the promises of the discourse might be unmet, the author conveyed that these might be signs of the need for change.

The second category of researches done by Briant (2015), Burr (2010), and Holmsten (2003) was showing how discourses, concepts, and thoughts on development affect approaches, policies, and implementation in the field.

Briant (2015) showed the influence of Keynesianism \& Neoliberalism in constructing Millennium Development Goals (MDGs) and the influence of these two plus liberal feminism and World Social Forum (WSF) in the formation of Sustainable Development Goals (SDGs). He contended that it was important for civil society to understand the intellectual economic foundation of these goals so that it would be able to choose whether to adopt or oppose methods for poverty alleviation.

The thesis applied a critical discourse approach towards exploring the construction of poverty and development within and across those goals. It explored Keynesianism and neoliberalism as the dominant economic discourses affecting those goals and how they shaped transnational frameworks for interpreting and mitigating poverty. The research questioned the failure of the MDGs, as expressed both by makers \& critics, and inquired into the constitution of the SDGs in light of these critiques. It also at the end explained the contradictions and new critiques of the SDGs.

The author saw that basically those goals have been shaped by hegemonic economic discourses that included Keynesian social welfare capitalism on one side, with its emphasis on government spending, engineering demand, and wealth distribution. And neoliberal free market capitalism with its approaches on economic deregulation, complete privatization, free trade, reduction in government size and spending, and creation of a strong private sector. 
The research argued that in the early 1980s neoliberal ideologies had a strong influence in major international organizations such as IMF, World Bank, and OECD. It contended that loans were only granted to developing countries after they implemented neoliberal macroeconomic adjustments, known as structural adjustment programs.

Apart from those two dominant intellectual underpinning of development concepts, the author also showed two prominent social discourses, these were liberal feminism and World Social Forum (WSF), which were resisting those dominant economic ideologies. Those proponents of WSF and feminists considered the MDGs "as a top-down creation of the world economic powers, propagated in an attempt to use poverty reduction and equality as a vehicle for neoliberal economic ideological dissemination and control."

The author showed that liberal feminism and the WSF with their competing values aimed "to establish gender equality within economic models, increase the voices of marginalized individuals, and advance locally controlled decision-making." These two social discourses in effect also succeeded in influencing the SDGs. Thus, the research basically made it visible how economic and social discourses influenced policies in global development frameworks.

As mentioned above, the studies done by Burr (2010) and Holmsten (2003) were basically intersected with the first category of studies and already discussed above. The main contention of Burr (2010) seen from the perspective of second category was basically that how the discourses on development was influenced by positivism and the historic-politico context of the Western enlightenment. Furthermore, she argued that essentially the concept of progress and the interventions to achieve it were value-based judgments. Unfortunately, this bias at the end also affected the work of development workers in developing countries. Consequently, development projects in developing countries became the instruments of the developed countries to transform, unsuccessfully, developing countries into the carbon copy of developed countries.

In Holmsten (2003)'s study, it was shown that how powerful neoliberal discourse has successfully influenced the policies of WB \& the IMF, and in turn affected policies of many developing countries in the world.

He researched that the neoliberal economic model was a set of economic principles that sought to reduce the barriers to trade and increase the exposure of domestic markets to the global economy. Among salient features of neoliberal policies include trade liberalization, opening capital and currency markets to international competition, and reducing the role of the government through cutting government services and privatizing state-owned enterprises. Supporters of the model believed that it would help alleviate poverty through promoting economic growth. Neoliberals contended that economic growth would be achieved through the market and increased trade and private investment, and not through government spending and regulation. Thus, he pointed out that neoliberal discourse influencing the policies of the World Bank and International Monetary Fund tended to expand the role of the market and reduce the role of the government.

The case shown in this study was in Malaysia and Indonesia during the Asian financial crisis (1997/8). The study contrasted the failure of Indonesia that followed the neoliberal discourse of WB \& IMF in dealing with the crisis and the relative success of Malaysia that did not subscribe to that discourse.

Finally, the last category of study on contemporary thoughts on development was done by Ramirez Faria (1989). He researched the origins of the economic inequalities between nations as manifested in the contemporary division between the developed and the underdeveloped countries. The following are some selected thoughts reviewed by the author.

First is Rosenstein Rodan. The author wrote that according to Rodan industrialization was the best and most efficient road to economic development. The research showed that Rodan at least gave five reasons for his view. First, rural sector was slow in taking up the employment as in the case of the dual economy theory. So, industrialization was expected to fill the gap. Secondly, it was the issue of externalities. Industrialization created external economies greater than agricultural sector. Here, the demand of one factory would create the assembly of another factory, and this new one would also create the need for making the other one so on and so forth. Thirdly, industrialization would steer the investment of "social 
overhead capital" in form of the development of public transportation, the creation of employment during its construction, and the rendering of permanent services to local communities. Fourthly, industrialization would also create "technological external economies," meaning that it would contribute to the training, on the job learning, and human capital formation. Finally, it was the concept of "big push", which was the main point of Rodan's idea. It was about bringing together investments in one vast area within a limited time limit.

The second one was thoughts expounded by Prebisch. Similar with Rosenstein Rodan, Prebisch also believed that industrialization was the way for the development of developing countries. However, the base of Prebisch's point was more on the import substitution industrialization (ISI). Prebisch contended that the prices of primary export commodities were deteriorating in relation to those of manufactured goods. This at the end would affect the foreign reserves of developing countries. To counter this, there would be a need to make manufactured goods, usually imported from developed countries.

The third thinker reviewed was H.W. Singer. The author stressed one aspect of the Singer's thought, that was, "on the "structural" nature of the unequal trade relations between the rich and the poor countries." This is what contributes to the underdevelopment process of developing countries. The research contended that according to Singer the problem of unequal trade was beyond a cyclical phenomenon, it was something similar with the situation described in economic-imperialism theory relating to exploitative international processes. Quoting Singer, the author noted three factors making the deterioration of the terms of trade of developing countries. First the relative deterioration of unit values for primary commodities exported by developing countries in relation to primary export unit values of developed countries. Secondly, the relative deterioration of manufactured export unit values of developing countries relative to manufactures exported by developed countries; and the lower proportion of manufactures in total exports of Least Developed Countries (LDCs) (for which unit values have increased less).

The fourth thinker was H.W. Arndt. According to the author, Arndt split the concept of development into two parts: growth and social objective. Capital accumulation, the development of human capital, and trade as the engine of growth was put under growth. For social objectives, it was the creation of employment and "basic needs." Arndt also discussed "structuralism" in his study on development. Structuralism here basically a critique toward the concept of price mechanism as a means to correct the balance of payment crises and other distortion. The structuralists believed that the government planning and controls should be looked into on this issue. Arndt as one of the structuralist development thinkers was of the view that price mechanism did not work well in underdevelopment than in developed countries, and therefore, classical economic theory generally was not applicable to LDCs.

The last two selected thinkers were Gunnar Myrdal \& W.W. Rostow. In contrast to Rostow considered to be among the proponent of modernization theory, Myrdal had a critical view toward the theory. He saw that many developing countries adopted the ideals of modernization as if it was a state religion. Egalitarian doctrine was considered as having a prominent role in the ideas of modernization. Enlightenment philosophy became so pervasive in influencing many public statements in many developing countries relating to objectives of planned development. However, based on his observations on some South Asian countries, Myrdal contended that instead of creating more equality, this modernization drive made even worse inequality. Here, Myrdal came up with the view that there was a need for the change of social and economic institutions and the attitude to push for development. Myrdal also attributed the failure of the state as one important factor contributing to underdevelopment. The state lacked solidarity and social discipline, and on top of that it was arbitrary and corrupt. The research showed that Myrdal interestingly took the case of Indonesia highlighting the facts that while corruption was seemingly not present during Dutch colonial rule, it began getting hold of theatrically after independence.

As mentioned above, Rostow was considered as the pioneer of the modernization theory. Combining the field of sociology and economics, he came up with his theory of economic development stages. Here, he laid out his theory on the stages of development of a country. Starting from traditional stage, it went on to the transitional stage, the take-off stage, the maturity, and finally the high-mass consumption stage. It was reported that Rostow was associated with the modernization theory through MIT-based Centre for 
International Studies (CENIS). CENIS was a CIA-funded think tank working on development that began officially in 1952 having intensive studies in India, Indonesia and Italy.

The research contended that the take-off stage was the main concern and target of the policy. The research showed that in this development stages theory the take-off stage was the short stage of development in which growth became self-sustaining. In this stage, for per capita income to have a steady increase to ensure sufficient future position of saving and investment, investment must go up exceeding $10 \%$ of national income. The research saw that Rostow recognized there would be transfers of resources from the rural to the urban economy.

The research found that Rostow was in favor of unbalanced growth in which some key industries paved the way creating forward, backward, and lateral linkages. In Rostow's perspective, growth was not an end in itself. It was only a means of a bigger change, which was transforming a traditional society into a modern society through among others technology and industrialization. The author saw that this Rostow's theory seemed to embody American foreign policy doctrine for the Third World during the late 50s and early 60s. On the basis of his reviews of a variety of development thoughts, he concluded that development is possible in developing countries, as opposed to some views that saw difficulties in the development of those considered as 'Third World' countries. However, he did not really specify on which concept of development he based his optimism on, whether on the existing dominant thoughts, which was not specified either 'which one?', or on alternative approaches like those put forward by other studies discussed above.

\section{CONCLUSION}

In investigating the concepts of development from conventional perspective, the study divided those researches into two main categories. First, those that discuss countries' case studies in examining the concept of development and their implication on those countries. The countries studied within this category are India, Mongolia, Bolivia, Indonesia, and Sub-Sahara Africa. Secondly, those that investigate more on the intellectual aspects of the development itself. Within this category, the subject can further be divided into three main thoughts.

First, it is related to the dominant concepts of development and why there is a need to come up with alternative approaches to development. Secondly, those researches that showed how discourses, concepts, and thoughts on development affect approaches, policies, and implementation in the field. And thirdly, research surveying a number of development thoughts that made the author conclude that development is possible in developing countries, as opposed to some views that saw difficulties in the development of those considered as 'Third World' countries.

The studies of Anjuman Ali-Bogaert (1997) and Bidney (2009) using the case of India and Mongolia respectively showed that the concept of development should not just rely on dominant development theories. These authors argued that development was a unique process for each and every country, and thus; Western-based development concepts should not be imposed on non-Western developing countries.

Other studies on Bolivia and Indonesia undertaken by Borda-Rodriguez (2008) and Lysaght (2008) respectively asserted that the imposition of Western-based dominant development discourses was in fact had taken places through many different forms in developing countries. Borda-Rodriguez (2008) raised the issue about the conception of the term "improvement." He saw that when the word "improvement" was used, it referred to a Western society and its associated lifestyle. Hence, the efforts done in making improvement would inevitably follow the historical process of capitalist development. As a result, main multilateral (World Bank, International Monetary Fund) and bilateral (donor country aid agencies such as the UK Department for International Development - DFID) development agencies would also guide the development into that direction.

Similarly, Lysaght (2008) also contended that what happened in Indonesia in the period that followed after the financial crisis 1997/98 was basically the imposition of IMF neoliberal agenda. However, he saw that this neoliberal agenda was a failure. According to him, IMF failed to achieve the very objectives that it wanted to achieve, that is, dismantling the power of oligarchy, eradicating corruption, and attracting the foreign direct investment back to Indonesia. These all did not happen between the period of 1998 and 2005. 
The author argued that the way IMF clung to and imposed neoliberal concepts on deregulation, privatization, and market dominance was damaging to developing countries.

Around the same thing like the above was also highlighted by Walton (2017) on Sub Sahara Africa (2017). In his exploration toward the concepts of wellbeing and sustainable development in rural SubSahara Africa, he found a persistent failure of free market capitalism development paradigm in the history of development discourses \& approaches in Sub-Saharan Africa.

On the basis of the above review, it can be concluded that researches on countries' case studies assess critically the concepts of development applied in some developing countries and their undesirable effects. However, except for Walton (2017), all of studies did not really give a specific alternative concept to present dominant development paradigm. The studies just suggest that there was a need to have some sort of 'tailormade' concepts of development to be applied in developing countries. The concepts that could consider the uniqueness of each and every country. As for Walton (2017), he was rather more specific in suggesting ecological economics as paradigm that could improve the welfare of the people. He opined that ecological economics might provide a paradigm for sustainable development that is culturally, ecologically, and economically more appropriate - and more effective - for both assessing and improving wellbeing.

On researches put under the second category, those that investigate more on the intellectual aspects of the development itself, while sharing the critical assessments of the researches in the first category, some also proposed alternatives to current approaches to development. Aftab (2003) proposed that autonomy should be the end of development whereas Burr (2010) put forward the need to have a flexible, self-reflexive practice of ethos that could speak to the aspirations of individuals in both privileged and subaltern positions to find commonalities with one another and work towards a more equitable world.

The other research (Bein-Meir, 2009) offered the concept of what he called 'alternative - participatory development.' Grant (1998) suggested that the alternative should be something that can reorient the concept of postmodernism so that it would be able to synthesize development theory on the basis of a combination between interest and ethics driven development imperatives.

\section{REFERENCES}

Aftab, Y. (2003). A Re-Conception of Progress: Autonomy Over Happiness as the End of Development [Unpublished master thesis]. Dalhousie University, Halifax, Nova Scotia.

Anjuman Ali-Bogaert, A. (1997). Imagining Alternatives to Development: A Case Study of the Narmada Bachao Andolan in India [Unpublished doctoral dissertation]. Kent State University, Kent.

Ben-Meir, Y. (2009). Participatory Development and Its Emergence in the Fields of Community and International Development [Unpublished doctoral dissertation]. The University of New Mexico Albuquerque, New Mexico.

Bidney, S.C. (2009). Contesting Development \& Globalization in Mongolia [Unpublished doctoral dissertation]. Indiana University, Indiana.

Borda-Rodriguez, A. (2008). Knowledge for Development: Reflections from Consultants \& Advisors in Bolivia [Unpublished doctoral dissertation]. Open University (United Kingdom).

Briant, J. (2015). Development Goals for the New Millennia: Discourse Analysis of the Evolution of the 2001 Millennium Development Goals and 2015 Sustainable Development Goals [Unpublished master thesis]. Arizona State University, Arizona.

Burr, J. (2010). The Altruistic Self and the Desire of Developing Others: Towards a Post-Development Ethos of Action [Unpublished master thesis]. Dalhousie University, Halifax, Nova Scotia.

Grant, I.M. (1998). Engaging the 'Frankenstein' of Modernity: Postmodernism and Development Theory [Unpublished master thesis]. The University of Guelph, Ontario.

Holmsten, S.S. (2003). Discourse Analysis of Neoliberalism [Unpublished master thesis]. American University, Washington.

Lysaght, G. (2008). Anatomy of a disaster: The IMF's war on corruption in Indonesia and the effects of structural adjustment [Unpublished doctoral dissertation]. University of Wollongong, New South Wales. 
Ramirez-Faria, C.B. (1989). The Origins of Economic Inequality Between Nations: An Historical Synthesis of Western Theories on Development and Underdevelopment [Unpublished doctoral dissertation]. London School of Economics \& Political Science, London.

Walton, J.S. (2017). Sub-Saharan Africa and a Crisis of Sustainability: Exploring Wellbeing and the Role of Ecological Economics in Sustainable Development [Unpublished doctoral dissertation]. Prescott College, Arizona.

80 Journal of Management Policy and Practice Vol. 22(4) 2021 